\section{US patent rulings will fuel invention}

On 13 June, the US Supreme Court denied the validity of patenting genes (Nature 498, 281-282; 2013) - but this is only part of the story. Since 2010 , the court has made three separate landmark rulings that give inventors full access to the wellspring of ideas, laws of nature and natural products.

Patent law requires ingenuity and invention for patenting a discovery. The Supreme Court established in 1980 that genetically modifying cells to eat oil, resist pesticides or produce insulin, for example, was a patentable invention.

After the draft human genome was released in 2001, the US Patent and Trademark Office stipulated that only genes of known function could be patented. Into this category fell $B R C A 1$ and BRCA2, the genes mutated in some breast and ovarian cancers, which were patented by the Utah firm Myriad Genetics. But questions arose hadn't the firm simply extracted a natural product? Did it 'own' the genetic information within?

The court subsequently ruled that a patent that pre-empts all uses of a natural product was disallowed (I was a plaintiff in the case). In separate cases in 2010 and 2012, it also ruled against patents that pre-empt all uses of an abstract idea or of a natural law.

I disagree that these rulings could stifle US innovation: they set a higher bar for genuine invention so that people will gain from better medicines and devices. And they will retain ownership of their genomes. Harry Ostrer Albert Einstein College of Medicine, New York, USA. harry.ostrer@einstein.yu.edu

\section{Will China expand on its carbon trading?}

China's current pilot schemes for carbon-emissions trading are the forerunners to a nationwide carbon market slated for 2016

(Nature 498, 145-146; 2013).

This has prompted international speculation that China might adopt an absolute cap on national emissions by 2020 . We contend that future Chinese climate policy is unlikely to rely mainly on cap and trade, and so will not depend on the success of pilot schemes.

In our view, the schemes are not likely to deliver a carbon price that reflects its social cost or provides an incentive for longterm investment in low-carbon technologies. The government may bring in other instruments in parallel (such as carbon taxes or mandatory emissions standards), which would distort the carbon price in China as they have in Europe.

The Chinese government should not allow the carbon prices emerging from its pilot trading schemes to distract attention from the real costs of moving to a low-carbon economy. Xi Liang, Francisco Ascui University of Edinburgh, UK. xi.liang@ed.ac.uk

David Reiner University of Cambridge, UK.

\section{Protection for trade of precious rosewood}

Madagascar's rosewood trees (Dalbergia spp.), prized for their hard, burgundy-coloured wood, are under threat after being exploited to make highquality furniture and musical instruments.

Earlier this year, rosewoods won greater trade protection at the Convention on International Trade in Endangered Species of Wild Fauna and Flora (CITES) conference in Bangkok. The challenge now, as for CITES designations globally, is to implement and enforce this protection.

Despite previous logging and shipping bans on hardwoods from Madagascar, and even a voluntary CITES Appendix III listing of five Dalbergia species in 2011, illegal logging has persisted in the wake of the country's political turmoil in 2009. The current Appendix II listing will create legal obstacles to illegal trade through a permit system that allows only non-detrimental harvesting practices.

Meredith A. Barrett University of California, San Francisco, USA. barrettm@chc.ucsf.edu

Jason L. Brown, Anne D. Yoder Duke University, Durham,

North Carolina, USA.

\section{Identical twins don't share fingerprints}

As chair of the Forensic

Identification Standards

Committee of the International

Association for Identification,

I would like to point out an

error in your obituary of

Joseph Murray regarding the

fingerprinting of identical twins

(Nature 493, 164; 2013).

Murray did ask for Richard

and Ronald Herrick to be

fingerprinted to determine

whether they were identical

before he transplanted a

kidney from one to the other

(J. E. Murray Surgery of the Soul;

Watson, 2001). Yet the Boston

police archives have no record of

the fingerprint request or of its

results (I. Truta and M. Sullivan, personal communication).

The twins' fingerprint

classification codes were probably tested for similarity, although this would not indicate twinning because unrelated people often share the same classification code. I could find no evidence that "the twins' fingerprints were identical", as the obituary states. Had they been, I am confident that forensic science would have taken notice in 1954.

Different people, including genetically indistinguishable twins, do not deposit identical fingerprints (see, for example, X. Tao et al. PLoS ONE 7, e35704; 2012).

John R. Vanderkolk Indiana

State Police Laboratory,

Fort Wayne, Indiana, USA.

vanderkolkjohn@yahoo.com

\section{Latin America should ditch impact factors}

Increased reliance on impact factors to evaluate scientific merit is having negative social and environmental effects in Latin America. We should abandon these indicators and concentrate on strengthening regional and national journals and networks for socially and locally relevant research.

Impact-factor rankings have damaged the region for several reasons. Because impact factors are generally low for conservation and ecology articles (compared with those in, say, biotechnology or medicine), these disciplines attract proportionately less funding. Top-tier journals tend to focus on global environmental issues to boost citation rates, at the expense of regionally important ones. And theoretical-ecology journals have higher impact factors than applied-ecology journals.

Together, these metrics are diverting researchers away from regional problems even as socioecosystems deteriorate around them. The South American biogeographic region comprises $10 \%$ of Earth's surface and hosts $50 \%$ of its biodiversity, yet the continent contributed less than $4 \%$ of global scientific output in 2010 (see go.nature.com/ hudjwn; in Spanish).

We suggest that Latin America should aim to achieve a genuine knowledge dialogue (see go.nature.com/ifrnlx; in Spanish) through confronting regional challenges, rather than focus on increasing its global "brain circulation" (Nature 490, 325; 2012).

Adrian Monjeau Fundación Bariloche; and CONICET, Argentina. amonjeau@gmail.com Jaime R. Rau University of Los Lagos, Osorno, Chile. Christopher B. Anderson CADIC-CONICET; and National University of Tierra del Fuego, Ushuaia, Argentina. 